\section{Names and Species of Ophiopogon Cultivated in the Southeastern United States}

\author{
Paul R. Fantz ${ }^{1}$
}

AdDitional Index words. Ruscaceae, Convallariaceae, Ophiopogonaceae, Liliaceae, morphology, ornamentals, ground covers, aztec grass, monkey grass, mondo grass, Liviope, Mondo

SumMARY. Species of Ophiopogon Ker-Gawl (aztec grass, monkey grass, mondo grass, and snake's beard) are versatile, evergreen, grass-like perennials used in a variety of landscape situations. The nursery/landscape industry commonly recognizes the Ophiopogon species O. japonicus (Linn. f.) Ker-Gawl and O. plansicapus Nakai, with O. clarkei Hook. f., O. intermedius D. Don, O. graminifolius (L.) Wehrh., O. jaburan (Sieb.) Lodd., O. kansuensis Bat., and O. obwii Okuyama available, but often misidentified and marketed under other names. Additional taxa are being introduced through botanic gardens and plant expeditions by horticulturists. A taxonomic treatment by the author of liriopogons cultivated in the southeastern United States had been in progress for nearly 15 years. Plants bearing the name O. graminifolius included additional misidentified species of Liriope Lour. and Ophiopogon. Plants bearing the name $O$. chingii Wang and Chang did not bear inflorescences, but vegetatively appear to be equivalent to $O$. graminifolius. Plants bearing the name $O$. mairei $\mathrm{H}$. Lév. and O. wallichianus (Kunth) J.D. Hook. were misidentified as Liviope exiliflora (L.H. Bailey) H.H. Hume. Additional taxa available in botanic gardens included $O$. bockianus Diels., O. bodnieri H. Lév., $O$. checkiangensis Koiti Kimura and Migo, O. chingii, and O. marmoratus Pierre ex L. Rodr. Plants bearing the name $O$. parviflorus (Hook. f.) Hara died without producing reproductive structures; thus, identification to even genus was unattainable. Ophiopogon arabicus Hort., O. nigra Hort., and O. nigrescens Hort. were invalid names used in the trade for $O$. planiscapus. This treatment includes original morphological descriptions from data obtained in the study, observational notes, and a table with a key to segregation of taxa.

$\mathrm{O}$ phiopogon (Ruscaceae Hutch, formally assigned to Convallariaceae Horan., Haemodoraceae Arnott, Ophiopogonaceae Kunth or Liliaceae Juss.) consists of evergreen, grass-like perennials used in landscapes as casual groundcovers in small areas, entryways, or courtyards, as borders along paths, edging beds, driveways, or sidewalks, in rock gardens, along streams, around bases of trees or shrubs, in containers, and around pools (Holmes

${ }^{1}$ Professor Emeritus, Department of Horticultural Science, North Carolina State University, Raleigh, NC 27695-7609

Salary and research support provided in part by Research Project NC0 6104, funded by the North Carolina Agricultural Research Service (NCARS; Raleigh, NC 27695-7643); publication funds received from the North Carolina Nursery and Landscape Association, Inc.

Thanks to Paul Lineberger, retired Superintendent, Horticultural Field Laboratory (Raleigh, NC) and his staff for cultural assistance with the germplasm collection used in this study, to those individuals, nurseries, and botanical gardens that donated plants for research, and to Frank Blazich, Anthony LeBude, Elizabeth Meyer, and Tom Ranney for their critical review of the manuscript.

The use of nursery and trade names in this publication does not imply endorsement by NCARS of the nurseries or the products mentioned, nor criticism of similar ones not mentioned. et al., 2001; Sunset Editorial Staff, 1997; Tenenbaum et al., 1994). Plants grow in filtered sun to full shade, and are regarded as fairly drought tolerant for short periods (Holmes et al., 2001; Huxley et al., 1992; Tenenbaum et al., 1994).

Species of Ophiopogon are commonly known as mondo grasses or monkey grasses, and less frequently as snake's beard or aztec grass (Fantz, 2008a; Huxley et al., 1992; Sunset Editorial Staff, 1997; Tenenbaum et al., 1994). The vernacular name aztec grass in the landscape/nursery industry is applied specifically to variegated selections of an Ophiopogon species often marketed as Liriope (Fantz, 2008a). In addition, monkey grass is applied to species of Liriope (Fantz, 2008a).

Two species are well known in the landscape-nursery industry,
$O$. japonicus and $O$. planiscapus (Holmes et al., 2001; Huxley et al., 1992; Sunset Editorial Staff, 1997; Tenenbaum et al., 1994). Available, but less well known are $O$. intermedius and O. jaburan. However, there are over a dozen names of species available in the trade, with rarer species being brought in by expeditions of specialized plant nurseries, collectors, and botanic gardens. The objectives of this article are to provide an inventory of cultivated species of Ophiopogon found in the southeastern United States during this study in the past decade, an original botanical description based upon research data, a key to their delineation and identification, and pertinent notes and observations. Also included will be additional cultivated taxa in the southeastern United States bearing species names of Ophiopogon that represent problems in accurate identification.

\section{Materials and methods}

Germplasm of liriopogons cultivated in the United States were accumulated and grown together from 1990 to 2005 in field plots at the Horticulture Field Laboratory (Raleigh, NC). Duplicate accessions and newly obtained, rare taxa were grown in the North Carolina State University Horticultural Science Greenhouse, located on the main campus behind Kilgore Hall in Raleigh. Newer accessions were added to the plots each spring. Plants were observed over the past decade, following procedures as described by Fantz (1994, 2008a). Data were obtained for morphological comparison, and descriptions of taxa provided herein were based upon observation and data collected from the plants being studied. Commentary on the phytography (descriptive morphology terminology) of various organs was presented under a discussion of the liriopogon genera (Fantz, 2008a) and is used herein (Table 1).

Measurements follow standard taxonomic procedures where a number in parenthesis is observed, but outside the typical range. For example,

\begin{tabular}{llll}
\hline $\begin{array}{l}\text { Units } \\
\begin{array}{l}\text { To convert U.S. to SI, } \\
\text { multiply by }\end{array}\end{array}$ & U.S. unit & SI unit & $\begin{array}{l}\text { To convert SI to U.S., } \\
\text { multiply by }\end{array}$ \\
\hline 2.54 & inch(es) & $\mathrm{cm}$ & 0.3937 \\
25.4 & inch(es) & $\mathrm{mm}$ & 0.0394
\end{tabular}


Table 1. Terminology used in describing the morphology of Ophiopogon. Measurements used are in standard taxonomic format; $\mathrm{x}-\mathrm{y}$ is common measurement range $(1 \mathrm{~mm}=\mathbf{0 . 0 3 9 4} \mathrm{inch})$.

General terms

Bib: a daughter plant with a few leaves; trade marketing term for sale of individual, daughter, liriopogon plants.

Liriopogon: general term applied to grass-like plants of the genera Liriope and Ophiopogon.

Phytography: general term for descriptive terminology (morphology) of plants and their component parts.

Plant structure

Caespitose: plants expand outward radially from crown of subterranean stem in dense tufts forming a mound or cushion on the ground.

Fibrous: roots numerous, filamentous (threadlike) roots, $0.5-2 \mathrm{~mm}$ diameter.

Fleshy: roots few, thickened, $2-4 \mathrm{~mm}$ diameter.

Primary root: main root axis borne from the subterranean stem bearing lateral secondary roots.

Rhizome: thickened, subterranean, stem with inconspicuous nodes, leaves appressed, inconspicuous, deteriorating quickly leaving veins.

Rhizomatous: plant bears a subterranean stem (caudex) with lateral shoots (rhizomes) that culminate in a daughter plant; often cited as stoloniferous in literature.

Secondary roots: lateral roots borne off of the primary root and typically smaller in diameter and shorter in length.

Stoloniferous: plant bears a prostrate stem laying on the soil surface, with leaves tufted (daughter plants) borne at nodes.

Storage organs: conspicuous swollen area or areas along the primary root length.

Leaves

Pliable leaf: leaves easily bent or folded upon itself by man, exhibiting minimal damage.

Rigid leaf: leaves thick-textured, resist bending or folding upon itself by man, and typically tearing at folding point.

Sheath: basal wing-like appendages to leaves, typically very thin, hyaline, translucent.

Inflorescences

Bract: modified leaf-like structure subtending a flower, borne at base of pedicel.

Fascicle: clusters of flowers or fruit borne laterally from the rachis.

Foliar bract: elongated, leaf-like bract, borne only early in season at the lowest inflorescence fascicle(s).

Inflorescence: a flowering branch; also used herein for a fruiting branch.

Loose fascicles: fascicles spaced apart with long rachis internodes, particularly at lower to middle rachis nodes.

Pedicel: stalk of the flower or fruit, measured from the node to the perigone base, or articulation point of Flora of China (2008).

Peduncle: stalk of the inflorescence, measured from the base to the node bearing the first buds, flower, or fruit.

Rachis: term for the portion of the inflorescence axis from which flowers and fruit are borne in fascicles.

Translucent: almost transparent structure as in the hyaline areas of leaves.

Flowers

Anther: pollen sac in a stamen borne at the apex of the filament.

Bud: an undeveloped flower.

Campanulate: bell-shaped flower, applied in Ophiopogon to the spreading perianth lobes.

Filament: stalk of the stamen.

Naviculate: surface bears a keel like a boat.

Ovary: expanded basal portion of pistil that bears the ovules; becomes fruit at maturity.

Perianth: general term that includes sepals and petals collectively, the floral envelope.

Perigone: fused perianth tube that narrows abruptly into a prolonged basal projection.

Petals: the inner whorl of the perianth.

Phalange: hyaline margin of bracts or leaves.

Perianth: term for sepals and petals collectively; alternate term used is tepals.

Perianth lobes: six free portions of the perianth with sepal lobes oriented outside and overlapping inner petal lobes.

Perianth tube: fused portion of the perianth, typically inconspicuous and very short in Ophiopogon.

Perigone: abrupt, basal, narrow cylindrical-shape of the perianth meeting the pedicel at the articulation point.

Petals: the inner whorl of the perianth.

Pistil: female reproductive organ of a flower, comprised of a basal ovary, a style, and the terminal stigma.

Sepals: the outer whorl of the perianth.

Stamen: male reproductive organ in a flower, comprised of a filament and an anther.

Style: narrow portion of pistil connecting stigma to the ovary.

an inflorescence “(6) 18-21 cm long” indicates that inflorescences as short as $6 \mathrm{~cm}$ are observed, but infrequently. Shorter inflorescences will occur late in the growing season, or in dwarf selections (Fantz, 2008a).

Plant vouchers were collected by P.R. Fantz for documentation of the taxa studied. Fantz assigned accession numbers to each voucher. Each taxa includes a sample of accession numbers of representative vouchers that will be deposited in national herbaria. The international designated acronym of each herbarium is enclosed in parenthesis (Holmgren et al.,
1990). The primary collection will be deposited in the North Carolina State University Herbarium, Department of Plant Biology, Raleigh (NCSC) and the National Arboretum Herbarium, Washington, DC (NA). Available duplicates will be sent to herbaria at Louisiana State University, 
Baton Rough (LSU), the Missouri Botanical Garden Herbarium, St. Louis (MO), and the University of Florida Herbarium, Gainesville (FLAS).

This treatment is a companion article to the one on Liriope (Fantz, 2008b). Unlike species of Liriope, several cultivated taxa of Ophiopogon did not survive. Root and storage organ data were obtained from new accessions before being placed in the greenhouse or field plots. Storage organs are the conspicuous swollen areas along primary roots as reported by Mularoni and Anderson (1987). Infrequently, taxa survived in field plots for a period of time, but never produced inflorescences. Thus, some vegetative data were obtained, but important data on reproductive characters needed for segregation and identification of the species were not observed by this author.

Morphological data of some taxa were incomplete in this study. Yet, these taxa are being grown in botanic gardens and some nurseries in the southeastern United States, often under a species name. These taxa may be propagated and become future plants introduced into the landscapes. Thus, the author decided to include these taxa in this treatment. Misidentified taxa are treated under their misidentified name being used, but noted with comments.

Morphological data obtained by the author will be provided in the descriptions. Taxa with limited vegetative descriptions were based upon data recorded by the author before they died, and are supplemented under observations with reproductive data from the Flora of China (2008) treatment and are cited under observations. Leaves, inflorescences, flowers, and fruit are bold-faced within morphological descriptions to allow readers to find more quickly the characters associated with these organs.

A dichotomous key (Table 2) is presented to assist in delineation, segregation, and identification of names and species of Ophiopogon currently found in the green industry and in botanic gardens in the southeastern United States. Multiple traits were used when possible for each couplet with contrasting characters, but incomplete data for some taxa resulted in a few couplets with one character cited.

Some taxa are being cultivated under a species name in which data are insufficient for reliable identification. Inclusion of these names does not recognize them as valid species being cultivated in the landscape/ nursery industry, but inclusion recognizes that these names currently exist in the industry, helps clarify some confusion with these names, and alerts others that these names may represent unreliable identifications.

An alphabetical treatment by species name is a useful tool of technology transfer for the reader, but may perpetuate misidentifications. Thus, taxa are segregated herein under two headings. Taxa arranged alphabetically by species of Ophiopogon represent those currently in cultivation. Synonyms will be included alphabetically, but direct one to the correct species name. Taxa arranged by name will include those with incomplete morphological data in this study, and are probably less reliable for accurate identification.

\section{Results and discussion}

Currently, the precise number of species of Ophiopogon is unknown. Bailey (1929) reported Ophiopogon as native to Asia and comprised of 20 species. Modern authors report 40 to 50 species in the genus (e.g., Beckett, 1983; Cutler, 1992) from eastern Asia. The International Plant Names Index (2008) database listed over 100 species names. Modern references that cite four to five to possibly 10 species (e.g., Holmes et al., 2001; Huxley et al., 1992; Tenenbaum et al., 1994) are referring to species reported to be cultivated in American landscapes. Visits and inquiries to major American herbaria in the early 1990s resulted in learning that liriopogon holdings totaled 10 or less vouchers of cultivated material, much of which were labeled as Liriope. At international meetings attended by the author, survey visits to the Kew Botanical Garden Herbarium, Kew, England (K), the Natural History Museum Herbarium, London (BM), and to the Royal Botanical Garden Herbarium, Edinburgh, Scotland (E), revealed an assemblage of obvious distinct species' vouchers filed under one name. A probable hypothesis was that botanists collecting native vouchers of the genus were unable to identify the vouchered species accurately from available literature descriptions. Thus, this genus is in need of a monographic revision, as delineation of the Asian species is problematic.

Fantz (1994) provided a chronological, taxonomic history of liriopogons. Bailey (1929) recognized six species under the genus Mondo Adans., a synonym of the conserved name Ophiopogon. Included were species reported as cultivated in America: $O$. intermedius (synonym Mondo intermedium L.H. Bailey), O. jaburan [synonym Mondo jaburan (Sieb.) L.H. Bailey], O. japonicus [synonym Mondo japonicum (Thunb.) Farw.], O. planiscapus [synonym Mondo planiscapum (Nakai) L.H. Bailey], and O. wallichianus (synonym Mondo wallichianum L.H. Bailey). Additional names appearing in nursery catalogs and literature included O. spicatus KerGawl (= Liriope spicata Lour.) and invalid names $O$. arabicus, $O$. nigra, and O. nigrescens (Fantz, 1994; International Plant Names Index, 2008; Tropicos, 2008).

Newer taxa being introduced into the United States include $O$. bockianus, O. bodinieri, O. checkiangensis, O. chingii, O. clarkii, O. formosanus Ohwii, O. graminifolius, $O$. kansunensis (synonym Liriope kansuensis C.H. Wright), O. marmoratus, $O$. ohwii, and O. parviflorus. Some taxa marketed under a species name were determined to be misidentified.

Several taxa of Ophiopogon were obtained by J.C. Raulston through the university arboretum, renamed after Raulston's death, and currently designated as the J.C. Raulston Arboretum, Department of Horticultural Science, North Carolina State University, Raleigh. Raulston provided bibs for this study and he provided bibs of one or more of these taxa to local nurserymen specializing in liriopogon collections.

Several taxa included dwarf selections marketed in the trade. Fantz (2008a) reported that traits such as leaf, inflorescence (scape), and peduncle lengths will increase with plant age, and inflorescences and peduncles are often shorter when produced late in the reproductive cycle. Cutler (1992) reported fruit as bearing a leathery capsule that ruptures early to expose the seed. Some descriptions reported seed data (e.g., Flora of China, 2008). In this study, both fruit and seed data are reported when observed, as most plants did not have the fruit rupturing 
Table 2. Key to names and species of Ophiopogon cultivated in the southeastern United States. Species names used for $O$. cekiangensis, $O$. chingii, $O$. maive $i$, and $O$. wallichianus probably represent misidentified taxa $(1 \mathrm{~mm}=0.0394 \mathrm{inch}, 1 \mathrm{~cm}=$ 0.3937 inch).

1. Plants caespitose; stems indistinct; daughter bibs clustered in one clump at caudex apex. O. bockianus

1. Plants rhizomatous or stoloniferous; stems distinct; daughter bibs borne at nodes or end of stems.

2. Stem terrestrial, stoloniferous, prostrate upon the soil surface.

3. Leaves 3-8 $\mathrm{mm}$ wide, $7-20 \mathrm{~cm}$ long, veins $5-9$.

3. Leaves $7-10 \mathrm{~mm}$ wide, $18-26 \mathrm{~cm}$ long, veins $11-13$. Unknown species misidentified as $\boldsymbol{O}$. chekiangensis

2. Stems subterranean, rhizomatous with stems below the oil surface.

4. Leaves broader, $5-15 \mathrm{~mm}$ wide.

5. Leaf petiolate, petiole $8-12 \mathrm{~mm}$; style $8 \mathrm{~mm}$; anthers $4 \mathrm{~mm}$ long.

O. marmoratus

5. Leaf sessile, petiole lacking; style $2.5-5 \mathrm{~mm}$ long; anthers $2-3 \mathrm{~mm}$ long.

6. Perigone conspicuous, $6-8 \mathrm{~mm}$ long; perianth lobes $6 \mathrm{~mm}$ long; anther $3 \mathrm{~mm}$ long; pedicel in flower 9-11 mm long; leaf sheath 6-9.5 $\mathrm{mm}$ long.

O. jaburan

6. Perigone inconspicuous, $1-2 \mathrm{~mm}$; perianth lobes $4-5 \mathrm{~mm}$ long; anther $2 \mathrm{~mm}$ long; pedicel in flower $2-5 \mathrm{~mm}$ long; leaf sheath $1.5-5.5 \mathrm{~mm}$ long.

7. Inflorescence 45-55 fascicled; rachis $8.5-21 \mathrm{~cm}$ long; leaf veins $13-23$; flowers 3-6 per fascicle; leaves typically variegated with longitudinal bands. ................................................................. O. intermedius

7. Inflorescence 5-18 fascicled; rachis $3-5 \mathrm{~cm}$ long; leaf veins $7-11$; flowers $1-3$ per fascicle; leaves typically green, variegated longitudinal bands lacking.

8. Scapes 19-22 cm long; style 4-5 mm long; perianth lobes 2-3 mm wide; fruit dark bluish-black, 6-7 mm diameter; leaves blackish, sometimes green.

O. planiscapus

8. Scapes 10-15 cm long; style $2.5 \mathrm{~mm}$ long; perianth lobes 1.5-2 mm wide; fruit bluish-gray, $8 \mathrm{~mm}$ diameter; leaves green.

O. mairei

4. Leaves narrower, $1-5 \mathrm{~mm}$ wide.

9. Flowers 13-16 $\mathrm{mm}$ diameter; style 5-7 $\mathrm{mm}$ long; perianth 6-8 $\mathrm{mm}$ long; sepal lobes 2.5-2.8 mm wide; petal lobes 3-3.2 mm wide.

10. Scapes 18-39 cm long; flowers white, purplish within; leaves (17) 25-42 cm long; pedicel 2-3 mm long; style exceeds stamens by $2.5-3 \mathrm{~mm}$; fruit $10-12 \mathrm{~mm}$ diameter.

O. clarkei

10. Scapes 5-9 cm long; flowers pink-lilaceous; leaves 12-20 cm long; pedicel 4-5 mm long; style exceeds stamens

by $1 \mathrm{~mm}$; fruit $7-9 \mathrm{~mm}$ diameter

O. obwii

9. Flowers 6-8 $\mathrm{mm}$ diameter; style 3-5 mm long; perianth 3-6 mm; sepal lobes $1.5-2.5 \mathrm{~mm}$ wide; petal lobes 2-3 mm wide.

11. Scapes 15-35 cm long; perianth lobes 4-6 mm long; pedicel 5-8 mm; filaments $0.5-0.8 \mathrm{~mm}$ long; fruit $-6 \mathrm{~mm}$ diameter; flowers several to many, white with purple within.

O. bodinievi

11. Scapes 2-9 (15) cm long; perianth lobes 3-4 mm long; pedicels $1.5-5 \mathrm{~mm}$ long; filaments $0.2-0.5 \mathrm{~mm}$ long; fruit 7-10 $\mathrm{mm}$ diameter; flowers few, pinkish to pinkish-lilaceous within.

12. Style $5 \mathrm{~mm}$ long, exceeding stamens by $2.5-3 \mathrm{~mm}$; bracts $7-9 \mathrm{~mm}$ long; rachis $2.8-4 \mathrm{~cm}$ long; leaves
3-5 mm wide.
O. kansuensis

12. Style $3.5-4.5 \mathrm{~mm}$ long, exceeding stamens by $1-1.5 \mathrm{~mm}$; bracts $2-7 \mathrm{~mm}$ long; rachis $1-2.3 \mathrm{~cm}$ long; leaves $1-3 \mathrm{~mm}$ wide.

13. Inflorescence fascicles $10-14$; fruit $8-10 \mathrm{~mm}$ diameter; bracts $2-4 \mathrm{~mm}$ long; perianth tube 3-4 mm long; anthers $2 \mathrm{~mm}$ long; style $3.5 \mathrm{~mm}$ long; pedicels 1.5-2 mm long. ... O. graminifolius

13. Inflorescence fascicles 6-9; fruit 7-8 $\mathrm{mm}$ diameter; bracts 4-6 $\mathrm{mm}$ long; perianth tube $2 \mathrm{~mm}$ long; anthers $2.7-3 \mathrm{~mm}$ long; pedicels $2-3 \mathrm{~mm}$ long.................................. O. japonicus

early. Fantz (2008a) reported that floral pigmentation varied in hues from year to year and within a season. Some taxa exhibited whitish flowers that sometimes bore a light pink to pale lilaceous hue, but not every season.

A key is provided in Table 2 to segregation and identification of names and species of Ophiopogon cultivated in the eastern United States, including misidentified taxa designated as such. Most couplets include several characters to aid segregation, including species with known dwarf selections. Further taxonomic study is needed, but data included herein will provide a contribution to the knowledge database of these species of Ophiopogon being introduced into botanic gardens and landscapes in the southeastern United States.

\section{Cultivated species of Ophiopogon} OPHIOPOGON ARABICUS. See $O$. planiscapus, cited below.

Representative vouchers. $5108,5310,5421,5916$, and 6217.

Observations. This name is an invalid species name (International Plant Names Index, 2008). This taxon is equivalent to $O$. planiscapus. Also, the name 'Arabicus' is treated as a cultivar name in the trade.

OPHIOPOGON BODINIERI (SYNONYM MONDO FORMOSANUM OHWI, OPHIOPOGON FORMOSANUS). Plants rhizomatous; rhizomes whitish, 10 to $26 \mathrm{~cm}$ long, 2 to $3 \mathrm{~mm}$ wide, internodes 15 to $25 \mathrm{~cm}$ long, ocra 15 to $20 \mathrm{~mm}$ long, deteriorating leaving veins and 3 to $4 \mathrm{~mm}$ long sheath. Roots fibrous, numerous; primary roots to $15 \mathrm{~cm}$ long, to $1 \mathrm{~mm}$ diameter; storage areas oblong, 6 to $12 \mathrm{~mm}$ long, 4 to $7 \mathrm{~mm}$ diameter. Leaves green, erect, and arching 
outward from near base to middle, 10 to $15(25) \mathrm{cm}$ long, 2 to $3 \mathrm{~mm}$ wide, basal sheath hyaline, 2.5 to $4.5 \mathrm{~cm}$ long, to $2 \mathrm{~mm}$ wide; veins 5-7. Inflorescences lacking.

Representative vouchers. 5851,6234 , and 6907.

Observations. Bibs were obtained from a nursery in China by the J.C. Raulston Arboretum (no. 930702), but did not survive. One bib planted in the liriopogon research bed survived weakly for 5 years, producing few leaves and lacking inflorescences. Voucher 6907 (vegetative state) was obtained at a local nursery labeled as O. formosana. Elliott (1997) noted this species as recent to gardens, forming clumps to $20 \mathrm{~cm}$ tall with flowers white and faintly tinged pink.

Flora of China (2008) states, inflorescence 15 to $35 \mathrm{~cm}$ long, several are many-flowered; rachis 1 to $7 \mathrm{~cm}$ long. Bracts linear, yellowish, $7 \mathrm{~mm}$ long. Pedicels 5 to $8 \mathrm{~mm}$ long. Flowers solitary or paired, white, purplish, or yellowish, tinged reddish. Perianth ovate-lanceolate to suboblong, 4 to $6 \mathrm{~mm}$ long, 1.5 to $3 \mathrm{~mm}$ wide. Filaments 0.5 to $0.8 \mathrm{~mm}$ long, anthers $\approx 2.5 \mathrm{~mm}$ long. Style 4 to 5 $\mathrm{mm}$ long. Fruit subglobose or ellipsoid, 5 to $6 \mathrm{~mm}$ diameter. Native to China where roots are used medicinally.

OPHIOPOGON CLARKEI. Plants rhizomatous, to $45 \mathrm{~cm}$ tall, becoming dense with age; rhizomes 1 to $3 \mathrm{~cm}$ long in young plants, to $30 \mathrm{~cm}$ long in older plants, 2 to $4 \mathrm{~mm}$ diameter. Leaves 20 to 24 per bib, dark green, graceful, and pliable, erect and nearly straight, arching 7 to $10 \mathrm{~cm}$ from apex, sessile, 17 to $42 \mathrm{~cm}$ long, 1.5 to $4 \mathrm{~mm}$ wide, serrulate, basal sheath hyaline, 5 to $10 \mathrm{~cm}$ long, $2 \mathrm{~mm}$ wide; veins 7 to 9 , midrib impressed above. Inflorescences hidden among leaves, 18 to $39 \mathrm{~cm}$ long; fascicles few, 5 to 8 ; peduncle green, weakly triangular to semiflattened, ridges translucentwinged, three-veined between ridges, 12 to 28 (34) cm long; arching to side and curved downward gracefully $\approx 5$ to $10 \mathrm{~cm}$ below rachis, sides flattened and 2 to $3 \mathrm{~mm}$ wide; rachis green tinged purple, longitudinally striated near ridge, 4 to $6.5 \mathrm{~cm}$ long, 2 to 3 $\mathrm{mm}$ wide. Bracts 2 below pedicels, green, 4 to $7 \mathrm{~mm}$ long, navicular with translucent wings, acute, 2 to $3 \mathrm{~mm}$ wide; inner bracts project lateral, navicular with translucent margins, 3 to $4 \mathrm{~mm}$ long, $1 \mathrm{~mm}$ wide; foliar bracts ovate-navicular with translucent wings; becoming linear above, (6) 9 to $15 \mathrm{~cm}$ long, 2 to $3 \mathrm{~mm}$ wide; bracts deciduous in fruit. Pedicels purplish-green to violaceous, striated, 2 to $3 \mathrm{~mm}$ long. Flowers 3 to 7 , nodding, solitary, (9) 13 to $16 \mathrm{~mm}$ diameter, white outside tinged purplish marginally, inner surface dark purple. Perianth $12 \mathrm{~mm}$ long, tube whitish, 3 (4) mm long, basal perigone 1 to $2 \mathrm{~mm}$ long, lobes lanceolate with thin translucent marginal wing, apex acute, slightly reflexed-spreading apically; sepal lobes $7 \mathrm{~mm}$ long, 2.7 to $2.8 \mathrm{~mm}$ wide; petal lobes 7.5 to $8 \mathrm{~mm}$ long, 3 to $3.2 \mathrm{~mm}$ wide. Stamens subsessile, shorter than style by 2.5 to $3 \mathrm{~mm}$; filaments white, 0.2 to $0.4 \mathrm{~mm}$ long; anthers yellow, saggitate, acute, $2 \mathrm{~mm}$ long, $0.8 \mathrm{~mm}$ diameter. Ovary white, (2) $3 \mathrm{~mm}$ diameter, style white, nearly straight, weakly incurved apically, 5 to $7 \mathrm{~mm}$ long; stigma minute, three-lobed, lobes $\approx 0.2 \mathrm{~mm}$ long. Fruit 1 to 4 per pedicel, green to bright green, becoming delph to cobalt blue, globular, 10 to $12 \mathrm{~mm}$ diameter; seed 7 to $8 \mathrm{~mm}$ diameter. Pedicels of fruit 5 to $7 \mathrm{~mm}$ long.

Representative Vouchers. 4403, 5297, 5386, 5539, 5734, 5988, $6102,6181,6114,6214,6435$, and 6506.

OBSERVATIONS. Infrequent, but available in trade, found primarily in botanic gardens. Flowers large and quite attractive as well as the larger blue fruit, but unfortunately these traits are hidden by the foliage, thus of little landscape value. I did observe a few semidouble flowers with two to three stamens bearing petaloid, purplish tissue, and lacking an anther. Occasionally misidentified as $O$. obwii.

OPHIOPOGON GRAMINIFOLIUS. Plants rhizomatous, to 8 to $18 \mathrm{~cm}$ tall; rhizomes to $25 \mathrm{~cm}$ long, 2 to 3 $\mathrm{mm}$ diameter. Leaves green, narrow, erect, arching $1 / 3$ to $3 / 4$ of length, 15 to $30 \mathrm{~cm}$ long, 1 to $2.5 \mathrm{~mm}$ wide, serrulate, basal sheath hyaline, 3.5 to $6 \mathrm{~cm}$ long, 2 to $3 \mathrm{~mm}$ wide; veins five, appear to alternate as broad and narrow (B-N-B-N-B). Inflorescences small, inconspicuous, hidden amongst leaves, 3 to $7 \mathrm{~cm}$ long, laterally compressed, few-flowered; peduncle 1.5 to $4.5 \mathrm{~cm}$ long, purplish above; rachis 1.5 to $2.3 \mathrm{~cm}$ long, purplish, angular; fascicles 10 to 14 . Bracts inconspicuous, purplish-green, ovate-lanceolate, acuminate, 2 to $4 \mathrm{~mm}$ long; inner bracts minute, deltoid, $\approx 0.2$ to 0.3 $\mathrm{mm}$ long. Pedicels quadrangular, purplish, 1.5 to $2 \mathrm{~mm}$ long. Flowers whitish to pinkish-lavender, solitary, nodding, campanulate. Perianth tube conspicuous, falcate, slender 3 to 4 $\mathrm{mm}$ long, lobes $4 \mathrm{~mm}$ long; sepal lobes $2 \mathrm{~mm}$ wide, petal lobes 1.8 $\mathrm{mm}$ wide. Stamens subsessile, shorter than style by $1.5 \mathrm{~mm}$; filaments subsessile, 0.2 to $0.3 \mathrm{~mm}$ long; anthers white tinged yellowish, lanceolate, gradually acute, $2 \mathrm{~mm}$ long. Style thick, $3.5 \mathrm{~mm}$ long; stigma inconspicuous, trifid. Fruit one to four per pedicel, green becoming blue, globular, 8 to $10 \mathrm{~mm}$ diameter; seed 6 to 8 $\mathrm{mm}$ diameter.

RePresentative VOUCHERs. 5716, 5724, 5892, 5896, 6106, $6182,6215,6445,6464,6506$, and 6515 .

Observations. In the trade, the epithet is confused, marketed as Liriope graminifolia Bat. as well as $O$. graminifolius. Liriope graminifolia is regarded as a synonym of Liriope spicata (International Plant Names Index, 2008). Plants labeled L. graminifolia in this study were equivalent to L. spicata (Fantz, 2008b). The plants described herein are marketed under the names $O$. graminifolius or O. japonicus. It is distinguished from O. japonicus by more fascicles in the inflorescence, smaller bracts, and smaller floral structures. It appears spreading and weedy when young, fills in as a dense groundcover with age. Not as invasive as L. spicata, but better used as a groundcover for banks and areas to prevent soil erosion. Leaves were often eaten by rabbits. Commonly referred to as monkey grass or mondo grass in the trade, names also associated with $L$. spicata and $O$. japonicus.

OPHIOPOGON INTERMEDIUS (SYNONYM MONDO INTERMEDIUM). Plants rhizomatous, 40 to $60 \mathrm{~cm}$ tall, dwarfs 12 to $18 \mathrm{~cm}$ tall, forming dense tufted mounds with age; rhizomes subwhite, 7 to $28 \mathrm{~cm}$ long, 1 to $2 \mathrm{~mm}$ diameter, nodes conspicuously thickened in a ring, internodes 5 to $11 \mathrm{~mm}$ long, ocra chartaceous, 1 to $3 \mathrm{~mm}$ long, soon disintegrating. Roots fibrous, 5 to $18 \mathrm{~mm}$ long, 0.5 to $1 \mathrm{~mm}$ diameter; secondary rootlets thin, 2 to $5 \mathrm{~cm}$ long, $\approx 0.1$ to $0.3 \mathrm{~mm}$ diameter; contractile roots white, thick, 4 to $16 \mathrm{~cm}$ long, 3 to $6(7)$ 
$\mathrm{mm}$ diameter; storage organs oblongoidal, 12 to $27 \mathrm{~mm}$ long, 3 to $6 \mathrm{~mm}$ diameter. Leaves erect to arching midway (arching near base in dwarf plants), variegated with yellow/ creme margins becoming white and one or more longitudinal creme or whitish bands, weakly serrulate, (20 to 35 ) 40 to $60 \mathrm{~cm}$ long, 7 to $12 \mathrm{~mm}$ wide, bands 0.3 to $1.0 \mathrm{~mm}$ wide, basal sheaths hyaline, 3 to 5.5 $\mathrm{cm}$ long, 2 to $4 \mathrm{~mm}$ wide; veins 13 to 23, midrib difficult to differentiate. Inflorescences conspicuous amongst leaves by elongation and projecting outward, (11.5 to 17.5 ) 22 to $37 \mathrm{~cm}$ long, many-flowered; peduncles compressed, striated, green tinged purplish with dark green striations, 9 to $17 \mathrm{~cm}$ long; rachis arching, laterally compressed, decurrent striated, green becoming whitish-green, (8 to 12.5 ) 17 to $21 \mathrm{~cm}$ long, fascicles (30 to 37 ) 45 to 55 , loosely arranged, lowermost internodes 8 to $15 \mathrm{~mm}$ between fascicles, other internodes 0.4 to $10 \mathrm{~mm}$. Bracts navicular, incurved, keeled, white with green phalanges, (4) 6 to $8 \mathrm{~mm}$ long, 1 to $2 \mathrm{~mm}$ wide basally, ovate-deltoid, rapidly tapering, acute; inner bracts project outward, ovate-navicular, 2 to $3 \mathrm{~mm}$ long, l to $1.5 \mathrm{~mm}$ wide. Pedicels quadrangular, greenishwhite, 2.5 to $5 \mathrm{~mm}$ long. Flowers (1) 3 to 6 per fascicle, white or faintly tinged pinkish, nodding, $6 \mathrm{~mm}$ diameter; buds 2 to $4 \mathrm{~mm}$ long. Perianth tube 1.5 to $1.8 \mathrm{~mm}$, lobes elliptic, broadly acute, concave, 4 to $5.3 \mathrm{~mm}$ long; sepal lobes 1.8 to $1.9 \mathrm{~mm}$ wide; petal lobes 2 to $2.1 \mathrm{~mm}$ wide; perigone 2.5 to $3 \mathrm{~mm}$ long; Stamens subsessile, shorter than style by 1 to $1.5 \mathrm{~mm}$; filaments white, $1 \mathrm{~mm}$ long; anthers sagittate, pale yellow, $2 \mathrm{~mm}$ long, $1 \mathrm{~mm}$ wide basally. Ovary white, $2 \mathrm{~mm}$ diameter; styles three, white, fused centrally, 2.5 to $3 \mathrm{~mm}$ long; stigma minute, trifid. Fruit not observed.

Representative vouchers. $4494,5045,5105,5223,5492$, $5697,5854,5905,5913,6064$, and 6235 .

Observations. This species is the one commonly known in the trade as Aztec grass. However, it is marketed commonly under Liriope muscari 'Variegated Evergreen Giant' or 'Grandiflora White'. Also, this species is confused with variegated selections of O. jaburan.
It is not cold hardy in the Raleigh, NC, area, and appears to do best in zone 10 where it produces dense mounds of ornamentally attractive variegated foliage with conspicuous scapes of white flowers projecting outward from amongst the leaves. In most of the eastern United States on into Canada, it commonly is used as an interior landscape plant.

There are dwarf selections in the nursery trade. Not surprisingly, these dwarf variegated forms are marketed as variegated mondo grass (O. japonicus), but are distinguished by the larger inflorescence and broader leaves. In the greenhouse, it became robust and crowded the pots, but never fruited. Flora of China (2008) cited seeds as ellipsoidal. In addition, $O$. wallichianum is regarded as a synonym (Flora of China, 2008), but plants obtained for this study under that name were misidentified as Liriope exiliflora.

OPHIOPOGON JABURAN (SYNONYM MONDO JABURAN). Weakly rhizomatous, to 12 to $21 \mathrm{~cm}$ tall; rhizomes whitish, 3 to $5 \mathrm{~cm}$ long, 3 to $4 \mathrm{~mm}$ diameter, nodal rings oblique, conspicuous, internodes 7 to $15 \mathrm{~mm}$ long, ocra 3 to $4 \mathrm{~mm}$ long; roots thick, elongate, 16 to $24 \mathrm{~cm}$ long, 2 to $3 \mathrm{~mm}$ diameter, secondary rootlets sparse, elongate, 0.5 to $1.7(5) \mathrm{cm}$ long, $1 \mathrm{~mm}$ diameter; storage organs clustered, ovate-ellipsoidal, 11 to 15 $\mathrm{mm}$ long, 8 to $13 \mathrm{~mm}$ diameter. Leaves stiffly pliable, dark green or variegated with yellow to creme (whitish with age) margins and longitudinal bands 1 to $3 \mathrm{~mm}$ wide, erect-spreading, arching in lower third to half its length, to 25 to 50 $\mathrm{cm}$ long, 7 to $15 \mathrm{~mm}$ wide, minutely serrulate, glaucous below between veins; veins 13 to 23 , impressed above; basal sheaths hyaline, 6 to 9.5 $\mathrm{cm}$ long, 3 to $7 \mathrm{~mm}$ broad. Inflorescences 25 to $35 \mathrm{~cm}$ long, overtopping leaves, semistraight to arching above, laterally compressed; fascicles 12 to 20 . Peduncle green, (17) 22 to $35 \mathrm{~cm}$ long, 4 to $7 \mathrm{~mm}$ wide; rachis pale green becoming whitish, 6 to $10.5 \mathrm{~cm}$ long, terete and compressed laterally, winged ridges, loose and open between fascicles with internodes 4 to $10 \mathrm{~mm}$ long. Bracts conspicuous, green medially, ovate-lanceolate, 4 to $13 \mathrm{~mm}$ long, $3 \mathrm{~mm}$ wide basally, margins hyaline, whitish, 1 to $5 \mathrm{~mm}$ wide, foliar bracts linear, 25 to $40 \mathrm{~cm}$ long, $2 \mathrm{~mm}$ wide with 2 to $3 \mathrm{~mm}$ wide hyaline margin. Pedicels white, (6) 9 to $11 \mathrm{~mm}$ long, curved downward apically. Buds white. Flowers white, nodding, campanulate, 3 to 7 per fascicle. Perianth tube $2 \mathrm{~mm}$ long, lobes $6 \mathrm{~mm}$ long, obtuse, weakly concaved, reflexed; sepals bluntly acute, 2 to $2.5 \mathrm{~mm}$ wide, petals obtuse, $3 \mathrm{~mm}$ wide; perigone 6 to $8 \mathrm{~mm}$ long. Stamens shorter than the style by 1.7 to $2 \mathrm{~mm}$; filaments subsessile, $1 \mathrm{~mm}$ long; anthers saggitate, acute, yellow, $3 \mathrm{~mm}$ long. Style $5 \mathrm{~mm}$ long. Fruit enclosed by dried perianth, oblongoidal, blackish, dark purplish to blue apically, bluish with age, 8 to $11 \mathrm{~mm}$ long, 7 to $8 \mathrm{~mm}$ diameter.

Representative vouchers. 5694, 6377, 6385, 6400, 6406, 6474 , and 6573.

Observations. Specialty plant in the green industry, often noted as white lilyturf or giant lilyturf (often misidentified as $O$. intermedius). Lilyturf is typically associated with Liriope (Fantz, 2008a). Research material was obtained from China, England, Germany, and from J.C. Raulston's collecting trip to Korea. In the United States, orders placed by the author for advertised plants of O. jaburan often were filled with substitutions as the advertised plant was unavailable. Available variegated selections (e.g., 'Vittatus') of the $O$. jaburan requested were sparsely filled, but included misidentified plants of O. intermedius. Variegated selections are most commonly used in interior landscapes and conservatories. Outside, the variegated selections usually did not survive into the second season. One plant survived, struggled for five seasons, and produced shorter and narrower leaves. Only once did it produce a short inflorescence with a few buds that never opened and aborted. The Korean plant Raulston collected with green foliage survived in the arboretum for several years, and was very showy and ornamental in bloom.

In interior greenhouses, plants quickly overgrow the pot, and become more robust with longer and broader leaves. Because named cultivars typically are variegated, their leaves are broader, produce longer inflorescences, and sometimes exhibit foliar bracts. Flowers are white, but one year they exhibited tinges of pink hues. 
OPHIOPOGON JAPONICUS (SYNONYM MONDO JAPONICUM). Rhizomatous plant 8 to $12 \mathrm{~cm}$ tall, producing numerous daughter plants, forming dense groundcover with age; caudex 1 to $1.5 \mathrm{~cm}$ long, knobby; rhizomes subterranean, 4 to $10 \mathrm{~cm}$ long, intertwined. Leaves pale green or yellowish-green to green, or variegated with longitudinal bands of yellow to creme, (6) 12 to $26 \mathrm{~cm}$ long, 2 to $3 \mathrm{~mm}$ wide, midrib inconspicuous; veins three to seven. Inflorescences hidden, inconspicuous, 2 to $5 \mathrm{~cm}$ long; peduncle erect, green, 1 to 3 $\mathrm{cm}$ long, $2 \mathrm{~mm}$ wide; rachis arching, greenish-white, 1 to $2 \mathrm{~cm}$ long, open and loose, internodes 3 to $6 \mathrm{~mm}$ long; fascicles 6 to 9. Bracts weakly navicular-lanceolate, 4 to $6 \mathrm{~mm}$ long, 1.5 to $2 \mathrm{~mm}$ wide, inner bracts 1.5 to $2 \mathrm{~mm}$ long; foliar bracts 7 to $8 \mathrm{~mm}$ long. Pedicels white, 2 to $3 \mathrm{~mm}$ long. Buds pale pinkish, 4 to $5 \mathrm{~mm}$ long. Flowers one to two per fascicle, pinkish tinged lilaceous. Perianth tube $2 \mathrm{~mm}$ long, lobes 3 to $4 \mathrm{~mm}$ long, sepals 1.4 to $1.6 \mathrm{~mm}$ wide, petals $2 \mathrm{~mm}$ wide. Stamens subsessile, $1 \mathrm{~mm}$ shorter than style; filaments $\approx 0.1$ to $0.2 \mathrm{~mm}$ long; anthers sagittate, 2.7 to $3 \mathrm{~mm}$ long, 0.6 to $0.7 \mathrm{~mm}$ diameter. Style 4 to $4.5 \mathrm{~mm}$ long. Fruit one to four per pedicel, subglobular, blue, 7 to $8 \mathrm{~mm}$ diameter; seeds white, 5 to $6 \mathrm{~mm}$ diameter.

Representative vouchers. 4469, 5026, 5038, 5156, 5313, 539, 5582, 5711, 5721, 585, 5926, 5938 , and 6101 .

Observations. Very common species in the green industry, particularly dwarf selections that make a nice mounding plant for planters, beds, and terrace gardens; a lawn substitute in the landscape and in model railroad displays, a filler in brick and stone walkways, an edging plant along walkways and in displays around water landscapes. Dwarf selections of other species with narrow leaves typically marketed as $O$. japonicus.

This species is confused commonly with Liriope spicata and infrequently with Liriope exiliflora in the nursery landscape trade as both are rhizomatous and bear narrower leaves. Both species of Liriope are common in landscapes in the southeastern United States. Liriope exiliflora can be distinguished easily by the bluish-violet flowers borne in 30 to 45 fascicles on tall inflorescences (17-29 cm long) with abundant black fruit in fall and winter. Liriope spicata has an erect rachis with star-like flowers oriented outward and upward (not nodding), and leaves 4 to 6 $\mathrm{mm}$ wide. Also, other narrow leaved species of Ophiopogon are marketed commonly as $O$. japonicus.

OPHIOPOGON KANSUENSIS (SYNONYM LIRIOPE KANSUENSIS). Rhizomatous plant forming a mound 7 to $11 \mathrm{~cm}$ tall, 1.5 to $2 \mathrm{~cm}$ wide; daughter plants $\approx 3 \mathrm{~cm}$ from parent plant. Roots fibrous, 15 to $17 \mathrm{~cm}$ long, to $1 \mathrm{~mm}$ diameter, secondary lateral rootlets sparse, to $2 \mathrm{~cm}$ long, $0.5 \mathrm{~cm}$ diameter; storage organs ellipsoidal, $1 \mathrm{~cm}$ long, 0.6 to $0.7 \mathrm{~mm}$ diameter. Leaves erect, arching apically, dark green, 6.5 to $13 \mathrm{~cm}$ long, 3 to $5 \mathrm{~mm}$ wide; veins 5 to 11 . Inflorescence overtopping leaves slightly, 8 to $9 \mathrm{~cm}$ long, $2 \mathrm{~mm}$ diameter, compressed terete; peduncle very dark green to blackish-purple, 5 to 6.5 $\mathrm{cm}$ long; rachis 2.8 to $4 \mathrm{~cm}$ long, internodes 4 to $9 \mathrm{~mm}$ long; fascicles five to six, loosely arranged, internodes 4 to $9 \mathrm{~mm}$ long. Bracts navicular, green, broadly hyaline-winged, 7 to 9 $\mathrm{mm}$ long, 1 to $3 \mathrm{~mm}$ wide, dark green center with hyaline margin; inner lateral bracts project laterally, 2 to 4 $\mathrm{mm}$ long, $1 \mathrm{~mm}$ wide. Pedicels falcate, $3 \mathrm{~mm}$ long, $1 \mathrm{~mm}$ diameter. Buds tinged purplish. Flowers one to three per fascicle, whitish tinged pale pink to lilaceous. Perianth tube 1.5 $\mathrm{mm}$ long, keeled, lobes $4 \mathrm{~mm}$ long, margins transparent; sepals $2 \mathrm{~mm}$ wide, petals $2.5 \mathrm{~mm}$ wide. Stamens subsessile, 2.5 to $3 \mathrm{~mm}$ shorter than style; filaments 0.1 to $0.2 \mathrm{~mm}$ long; anthers sagittate, falcate, pale white tinged yellowish, 1.6 to $1.8 \mathrm{~mm}$ long, 0.5 to $0.6 \mathrm{~mm}$ diameter. Ovary $2 \mathrm{~mm}$ diameter; style falcate, $5 \mathrm{~mm}$ long; stigma trifid. Fruit subglobular, shiny dark green, 8 to $9 \mathrm{~mm}$ diameter. Pedicels of fruit 4 to $4.5 \mathrm{~mm}$ long.

Representative VOUCHERs. 5762,5870 , and 6113 .

Observations. Specialty plant was obtained in J.C. Raulston Arboretum collection from Germany. Plants did not survive in research plots. Bibs were given by Raulston to a few nurserymen specializing in liriopogons, but I have not observed this name appearing in trade catalogs.

OPHIOPOGON NIGRA OR O. NIGRESCENS. Invalid names for species with vernacular name of black mondo grass; plants equivalent to $O$. planiscapus. Also, 'Nigrescens' is used as a cultivar name.

Representative vouchers. 5122, 5143, 5233, 5270, 5373, 5413, 5439, 5722, 5759, 5890, 5917, 6110, and 6202 .

OPHIOPOGON OHWII. Rhizomatous; caudex inconspicuous, 6 to 10 $\mathrm{mm}$ long. Roots fibrous, elongate, 8 to $15 \mathrm{~cm}$ long, $1 \mathrm{~mm}$ diameter; secondary lateral rootlets sparse, 0.5 to $2 \mathrm{~mm}$ long, $\approx 0.3$ to $0.6 \mathrm{~mm}$ diameter; storage organs ellipsoidal, 7 to $12 \mathrm{~mm}$ long, 3 to $7 \mathrm{~mm}$ diameter. Leaves dark green, pale below, 12 to $21 \mathrm{~cm}$ long, 3 to $4 \mathrm{~mm}$ wide, serrulate, basal sheath hyaline, 2 to $2.5 \mathrm{~cm}$ long, 2 to $3 \mathrm{~mm}$ wide; veins three to five, impressed above, raised below. Inflorescences hidden by leaves, 6 to $9 \mathrm{~cm}$ long; peduncle green, 4 to $6.5 \mathrm{~cm}$ long, $2 \mathrm{~mm}$ wide; arching between 3 to $4 \mathrm{~cm}$ of length, laterally angular compressed, rachis open and lax, light green becoming pinkish to pale lavender above, 3.5 to $4.5 \mathrm{~cm}$ long; fascicles 7 to 10 . Bracts navicular, 1-nerved, 3 to $5 \mathrm{~mm}$ long, phalanges greenish-brown; foliar bracts 8 to $10 \mathrm{~mm}$ long. Pedicels pinkish, quadrangular, 3 to $5 \mathrm{~mm}$ long. Buds pink to tinged lavender. Flowers pinkish to pale lilaceous, campanulate, $14 \mathrm{~mm}$ diameter. Perianth tube 1 $\mathrm{mm}$ long, perigone 2 to $3 \mathrm{~mm}$ long, lobes 3 to $4 \mathrm{~mm}$, reflexed apically; sepals $2.5 \mathrm{~mm}$ wide; petals $3 \mathrm{~mm}$ wide, margins thin, slightly pigmented. Stamens shorter than style by $1 \mathrm{~mm}$; filaments 0.4 to $0.5 \mathrm{~mm}$ long; anthers light yellow, base broad abruptly long aculinate, apex acute, 1 $\mathrm{mm}$ long, $1 \mathrm{~mm}$ diameter. Style pinkish, $6 \mathrm{~mm}$ long, $1 \mathrm{~mm}$ diameter. Fruit subglobular, one to four per fascicle, 7 to $9 \mathrm{~mm}$ diameter; seeds brown, 6 to $8 \mathrm{~mm}$ diameter.

RePRESENTATIVE VOUCHERS. $5250,5430,5485,5488,5710$, $5717,5727,5739,5857,5897$, and 6216 .

ObServations. Specialty plant in trade, more commonly found in botanic gardens. Occasionally found marketed under the name O. japonicus.

OPHIOPOGON PLANISCAPUS. Rhizomatous, (8) 30 to $35 \mathrm{~cm}$ tall, daughter plants 4 to $24 \mathrm{~cm}$ away from parent plant. Roots dull yellowish. Leaves firm-pliable, erect, arching near apex, deep green to dark 
purplish-black, greenish below, bluntly acute, (10) 25 to $36 \mathrm{~cm}$ long, 4 to 9 (12) $\mathrm{mm}$ wide, serrulate, basal sheaths hyaline, $1.5 \mathrm{~cm}$ long, $3 \mathrm{~mm}$ wide; veins 7 to 11 , midrib broad, $\approx 0.6$ to $0.7 \mathrm{~mm}$ wide. Inflorescences (6) 19 to $21 \mathrm{~cm}$ long; peduncles purplish-black, flattened, (4) 12 to $16 \mathrm{~cm}$ long; rachis (2) 3.5 to $5 \mathrm{~cm}$ long, flattened, thin translucent wings marginally, open and lax, first internode 7 to $10 \mathrm{~mm}$ long, upper 4 to $7 \mathrm{~mm}$ long; fascicles (5) 12 to 18 . Bracts navicular-lanceolate, green to greenish-black, margins thin hyaline, 1-nerved, 4 to $7 \mathrm{~mm}$ long, 1 to 1.5 $\mathrm{mm}$ wide basally; inner lateral bracts 3 to $4 \mathrm{~mm}$ long, 0.5 to $0.7 \mathrm{~mm}$ wide, perpendicular to primary bract; foliar bracts 8 tol $2 \mathrm{~mm}$ long. Pedicels black, 2 to $4 \mathrm{~mm}$ long. Buds tinged purplish to dark lavender. Flowers campanulate, white with pink to pale lavender tinge, bluish-lavender within, one to three per fascicle, nodding to upturned. Perianth tube 1 to $1.5 \mathrm{~mm}$ long, perigone 1 to $2 \mathrm{~mm}$ long, lobes $4 \mathrm{~mm}$ long; sepals $2 \mathrm{~mm}$ wide, petals 2.5 to $3 \mathrm{~mm}$ wide. Stamens subsessile, shorter than style by 1.5 to $2 \mathrm{~mm}$; filaments $\approx 0.4$ to 0.6 $\mathrm{mm}$ long; anthers lanceolate, dull yellow, sagittate, $2 \mathrm{~mm}$ long, 0.6 to $0.8 \mathrm{~mm}$ diameter. Ovary $3 \mathrm{~mm}$ diameter; style whitish, weakly falcate, 4 to $5 \mathrm{~mm}$ long. Fruit blackish, subglobular, one to two per pedicel, 6 to 7 $\mathrm{mm}$ diameter.

Representative vouchers. 5122, 5143, 5403, 5439, 5644, 5722, 5890, 5893, 5954, and 6202.

Observations. Prized landscape groundcover for its unusual, distinctive blackish foliage and conspicuous, showy flowers for an Ophiopogon sp. Less desirable traits include slow growth rate, "weedy" appearance due to daughter plants being widely spaced away from parent plant and not forming mounds with age, and some selections producing daughter plants with green leaves after a few years. Green-leaved selections are confused occasionally with L. spicata, a species that is more invasive with fast growth.

\section{Species names of cultivated Ophiopogon}

The species names of Ophiopogon cited below are found in current literature (e.g., Elliott, 1997) or on taxa cultivated in the southeastern
United States. These taxa may be misidentified.

OPHIOPOGON BOCKIANUS. Plants caespitose; caudex elongated, bearing bibs clustered at nodes. Roots sparse, fibrous; primary roots 5 to $25 \mathrm{~cm}$ long, 1 to $2.5 \mathrm{~mm}$ diameter; secondary lateral rootlets rare, to $1 \mathrm{~mm}$ diameter; storage organs 2 to $5 \mathrm{~mm}$ long, 3 to $5 \mathrm{~mm}$ thick. Leaves green and smooth above, slightly glaucous below, 10 to $13 \mathrm{~cm}$ long, 5 to $7 \mathrm{~mm}$ wide, margins seemingly smooth, but minutely serrulated at $30 \times$; veins seven to nine. Inflorescences lacking.

REPRESENTATIVE VOUCHERS. None, as bibs obtained died in less than 1 month.

Observations. Bibs were obtained from a botanic garden in England. Probably not in current cultivation in the United States. Flora of China (2008) states, inflorescence 18 to $28 \mathrm{~cm}$ long, more than 10 flowered; rachis 5 to $14 \mathrm{~cm}$ long; bracts lanceolate, 12 to $15 \mathrm{~mm}$ long; pedicels 6 to $9 \mathrm{~mm}$ long; flowers paired, purplish. Perianth ovate, 6 to $7 \mathrm{~mm}$ long, 2 to $3 \mathrm{~mm}$ wide, apex recurved. Filaments very short; anthers 2.5 to $3 \mathrm{~mm}$ long. Style 5 $\mathrm{mm}$ long. Fruit $10 \mathrm{~mm}$ long, $8 \mathrm{~mm}$ diameter. Native to China.

OPHIOPOGON CHEKIANGENSIS. A misidentified species in this study. Plants stoloniferous forming a mound of daughter plants; stems (stolons) prostrate on soil surface, 3 to $4.5 \mathrm{~cm}$ long, 2 to $4 \mathrm{~mm}$ diameter. Roots of daughter plants becoming intertwined; primary roots whitish, to $8 \mathrm{~cm}$ long, 4 to $5 \mathrm{~mm}$ wide; secondary rootlets 8 to $25 \mathrm{~cm}$ long, 1 to $2 \mathrm{~mm}$ wide; storage organs ellipsoidal, 13 to $15 \mathrm{~mm}$ long, 4 to $5 \mathrm{~mm}$ diameter near middle, gradually tapering toward both ends. Leaves green, 2-ranked and complicate-channeled basally, ascending and abruptly opening above, 18 to $26 \mathrm{~cm}$ long, 7 to 10 $\mathrm{mm}$ wide apically, $5 \mathrm{~mm}$, basal sheath whitish, 11 to $17 \mathrm{~mm}$ long, 1 to $3 \mathrm{~mm}$ wide beyond blade, to 3 to $7 \mathrm{~mm}$ folded sides at leaf base; veins 11 to 13 , impressed with midrib raised below. Inflorescences lacking.

RePresentative vouchers. 5419,5812 , and 5871 .

Observations. Plants formed a mounded population by the second year (1993), but never produced inflorescences. In the following year, plants survived weakly with sparse new bibs and were dead by Aug. 1995. These plants were obtained by the J.C. Raulston Arboretum from China. This species name was included as a synonym for O. japonicus in the treatment for China (Flora of China, 2008; Tropicos, 2008). However, our plants were distinct from O. japonicus with their terrestrial prostrate stems and broader leaves; thus, this research plant probably was misidentified at the source. Difficult to identify correctly our taxon from other species of Ophiopogon with prostrate stems, as reproductive data are lacking.

OPHIOPOGON CHINGII. Rhizomatous. Roots sparse, primary root to 14 $\mathrm{cm}$ long, $1 \mathrm{~mm}$ wide; secondary lateral roots very sparse, to $4 \mathrm{~cm}$ long, $\approx 0.2$ to $0.3 \mathrm{~mm}$ wide. Leaves green, 15 to $21 \mathrm{~cm}$ long, 1 to $1.5 \mathrm{~mm}$ wide, phalange hyaline, 2.4 to $3 \mathrm{~cm}$ long, 3 to $4 \mathrm{~mm}$ wide; veins five, midrib indistinguishable, veins appearing to alternate as broad (B) and narrow $(\mathrm{N})$, as $\mathrm{B}-\mathrm{N}-\mathrm{B}-\mathrm{N}-\mathrm{B}$.

REPRESENTATIVE VOUCHER. 6906.

Observations. The vegetative voucher (no. 6906) of a plant in a North Carolina nursery labeled as $O$. chingii was probably misidentified as it does not match the description of O. chingii (Flora of China, 2008). Vegetatively, the plant in this study appears similar to those marketed as O. graminifolius. Elliott (1997) cited $O$. chingii as a recent introduction with very narrow leaves, white flowers, and blue fruit, a qualitative description that could apply to several species of Ophiopogon. However, Flora of China (2008) cited this species as having prostrate stems and broader leaves.

Flora of China (2008) states: Stem prostrate, elongated, 2 to 5 $\mathrm{mm}$ thick. Leaves scattered, subsessile, glaucous below, sword-shaped, 7 to $20 \mathrm{~cm}$ long, 3 to $8(20) \mathrm{mm}$ wide; veins five to nine. Inflorescence arising from distal leaf axil, 8 to $15 \mathrm{~cm}$ long, 5- to 10-flowered. Bracts white, ovate to lanceolate, scarious, $6 \mathrm{~mm}$ long. Pedicels 6 to $12 \mathrm{~mm}$ long. Flowers clustered two to four or solitary, white or purplish. Perianth oblong to ovate-oblong, $5 \mathrm{~mm}$ long, $2 \mathrm{~mm}$ wide. Filaments $1 \mathrm{~mm}$ long; anthers $\approx 2 \mathrm{~mm}$ long. Style 3 to $4 \mathrm{~mm}$ long.

O. FORMOSANUS. See O. bodnieri above. 
OPHIOPOGON MAIREI. A plant bearing the name Liriope maireii is being grown at a local nursery south of Raleigh, NC. The plant is not an Ophiopogon, but is equivalent to Liriope exiliflora.

REPRESENTATIVE VOUCHER. 6900.

Observations. Fantz (2008b) reported that the name $L$. maireii is a name lacking in modern indexes (International Plant Name Index, 2008; Tropicos, 2008). The plant was obtained from China. Apparently someone at the nursery recognized that the plant was a member of the genus Liriope and transferred the epithet. This species probably is not in cultivation in the southeastern United States.

Flora of China (2008) states: Rhizomatous. Leaves 20 to $40 \mathrm{~cm}$ long, 7 to $14 \mathrm{~mm}$ wide, glaucous below, margin serrulate; veins nine. Inflorescence 5 to $7 \mathrm{~cm}$, manyflowered. Bracts subulate, 5 to 7 $\mathrm{mm}$ long. Pedicels 3 to $5 \mathrm{~mm}$ long. Flowers white to blue, one to two per fascicled. Perianth 4 to $5 \mathrm{~mm}$ long, 1.5 to $2 \mathrm{~mm}$ wide. Filaments $0.5 \mathrm{~mm}$ long; anthers $2 \mathrm{~mm}$. Style $2.5 \mathrm{~mm}$ long. Fruit ellipsoidal to ovoid-globose, bluish-gray, $8 \mathrm{~mm}$ diameter.

OPHIOPOGON MARMORATRUS. Bibs with roots thick, fibrous, 7.5 to $28 \mathrm{~cm}$ long, 2 to $4 \mathrm{~mm}$ diameter; secondary lateral rootlets and storage organs lacking. Leaves petiolate, oblinear, tapering gradually toward apex and into petiole, green above, glaucous between veins below; blade 10 to $13 \mathrm{~cm}$ long, 6 to $9 \mathrm{~mm}$ wide; petiole 2 to $4 \mathrm{~cm}$ long; veins 11 to 19 .

Representative Voucher. None.

Observations. Bibs were obtained by J.C. Raulston Arboretum from England. Plants did not survive. It is probably not currently in the nursery/landscape industry in the United States. Species is different from all others by the distinct petiolate leaves. The description above was obtained from immature plants with three to five leaves per bib. All three bibs obtained in June were dead by mid-September.

Flora of China (2008) states: Leaves narrowly oblong, 13 to 18 $\mathrm{cm}$ long, 18 to $25 \mathrm{~mm}$ wide, acute to short-acuminate, attenuate; petiole 8 to $12 \mathrm{~cm}$ long; veins 7 . Inflorescences 10 to $13 \mathrm{~cm}$, long 15 to 20 flowered. Bracts ovate, $10 \mathrm{~mm}$ long.
Pedicels $8 \mathrm{~mm}$ long. Flowers white, one to three per fascicle. Perianth oblong-lanceolate, $8 \mathrm{~mm}$ long, 1.5 to $2.5 \mathrm{~mm}$ wide. Anthers $4 \mathrm{~mm}$ long. Style $8 \mathrm{~mm}$ long.

OPHIOPOGON PARVIFLORUS. Rhizomatous. Roots fibrous, 15 to $20 \mathrm{~cm}$ long, $1 \mathrm{~mm}$ diameter; secondary lateral rootlets sparse, 1 to $2 \mathrm{~cm}$ long, 0.3 to $0.5 \mathrm{~mm}$ diameter; storage organs ellipsoidal, 1 to $5 \mathrm{~cm}$ long, 6 to $9 \mathrm{~mm}$ diameter. Leaves juvenile, green, erect, 2 to $5 \mathrm{~cm}$ long, basal sheaths hyaline, 4 to $5 \mathrm{~cm}$ long, 1 to $2 \mathrm{~mm}$ wide, 4 to $7 \mathrm{~mm}$ wide; veins 11 to 13 .

Representative vouchers. None, as plant did not survive.

Observations. Bib received from England and data cited above were recorded before planting. Plants exhibited poor growth and were dead by the end of the season. This name was published originally as a variety of O. intermedius. Difficult to distinguish the plant as a Liriope or an Ophiopogon from the scant data available in this study. Currently, plants with this name are not in the United States trade.

OPHIOPOGON WALLICHIANUS. Plant material in this study was misidentified taxa of Liriope.

Representative vouchers. 5940,6213 , and 6220 .

OBSERVATIONS.

wallichianus is cited as a of $O$. inus is cited as a synonym 2008). Bibs obtained for this study from England were misidentified and equivalent to Liriope exiliflora. Bibs obtained from China died shortly, but appeared to be Liriope spicata. Neither of these plants exhibited variegated foliage that is typical of selections found in the United States of O. intermedius.

\section{Conclusions}

A monographic revision of the genus Ophiopogon native to eastern Asia is needed to delimit species, and provide taxonomic treatments of taxa and keys to segregation and identification of species. A revision would make it possible to accurately identify those species being brought into the United States through plant expeditions, exchanges, and purchase, and being introduced into the landscape.

Based upon this study, eight species are available currently in the industry trade. These include $O$. clarkei, O. graminifolius, O. intermedius, $O$. jaburan, $O$. japonicus, $O$. kansuensis, $O$. obwii, and $O$. planiscapus. Misidentifications of these taxa are common! These plants often are marketed under other names, including as taxa of Liriope. Plants bearing names of $O$. bockianus, O. bodnieri, O. chekiangensis, O. chingii, O. mairei, and O. marmoratus are being introduced into gardens in the United States, but also may not be identified correctly. A number of new taxa are being introduced and marketed under cultivar names, but lack any indication of a species name, nor are assigned to a familiar species name.

\section{Literature cited}

Bailey, L.H. 1929. The case of Ophiopogon and Liriope. Gentes Herbarium 2:337.

Beckett, K.A. 1983. The concise encyclopedia of garden plants. Orbis Publishing, London.

Cutler, D.F. 1992. Vegetative anatomy of Ophiopogoneae (Convallariaceae). J. Linnean Soc. 110:385-419.

Elliott, J. 1997. The smaller perennials: An illustrated guide to over 3000 plants ideal for small gardens. Timber Press, Portland, OR.

Fantz, P.R. 1994. Taxonomic problems in cultivated liriopogons. HortTechnology 3:146-150.

Fantz, P.R. 2008a. Macrophytography of cultivated liriopogons and genera delineation. HortTechnology 18:334342 .

Fantz, P.R. 2008b. Species of Liriope cultivated in the southeastern United States. HortTechnology 18:343-348.

Flora of China. 2008. Ophiopogon. 29 July 2008. <http://www.efloras.org/browse. aspx?flora_id=2\&start_taxon_id= 122994>.

Holmes, R., R. Buchanan, and F. Tenenbaum. 2001. Taylor's master guide to gardening. Houghton Mifflin, New York.

Holmgren, P.K., N.H. Holmgren, and L.C. Barnett. 1990. Index herbarium. Part I: The herbaria of the world, 8th ed. International Assn. Plant Taxonomy, New York.

A. Huxley, M. Griffiths, and L. Margot (eds.). 1992. The new Royal Horticultural Society dictionary of gardening. MacMillan, London. 


\section{Research Reports}

International Plant Names Index. 2008.

The International Plant Names Index, Plant name query. 29 July 2008. <http://www.ipni.org/ipni/ plantnamesearchpage.do $>$.

Mularoni, T.C. and C.E. Anderson. 1987. Growth of Liriope muscari in response to various temperatures, photo- period and nutrient combinations. North Carolina State Univ. Phytotron Rpt. p. 36-49.

Sunset Editorial Staff. 1997. Sunset national garden book. Sunset Books, Menlo Park, CA.

Tenenbaum, F. R. Buchanan, and R. Holmes (eds.). 1994. Taylor's master guide to gardening. Houghton Mifflin, New York.

Tropicos. 2008. Tropicos name search. 29 July 2008. <http://www.tropicos. org/NameSearch.aspx?name $>$. 